\title{
Landslide Disaster Potential Mapping in Feasibility Study of Walini Area as the Candidate for the Capital City of West Java
}

\author{
Putra, R. R. ${ }^{1 *}$, Renaldi, I.G.M. ${ }^{1}$, Rahman, H.T. ${ }^{1}$, Aulya, F. ${ }^{1}$, Muslim, D. ${ }^{2}$ and Sadewo, M.S. ${ }^{3}$ \\ ${ }^{I}$ Geological Engineering Bachelor Program, Department of Geological Engineering, Padjadjaran University, Indonesia \\ ${ }^{2}$ Department of Geological Engineering, Padjadjaran University, Indonesia \\ ${ }^{3}$ Geological Engineering Master Program, Institute Technology of Bandung, Indonesia
}

\begin{abstract}
Walini, Cikalongwetan District, West Bandung Regency is one of the 3 plans for the relocation of the capital city of West Java. This area is also projected to become a high-speed train station from Bandung City to Jakarta. This paper is aimed to reveal the feasibility of the Walini area based on landslide potentials. The methodology of this research is the Weighted Linear Combination (WLC) method using the parameters of Landslide Hazard Assessment parameters (rainfall, geology, slope, elevation, vegetation) and Landslide Vulnerability Assessment parameters (population, LULC, proximity to the road, proximity to stream). The results show that this area has 5 classes of risk, from Very Low to Very High. Kanangasari Village is filled by Moderate to Very High Class but the dominant class is High with an area $8,179 \mathrm{~km}^{2}(68,01 \%$ of the area). Mandalasari and Mandalamukti are in High to Very High Class. Very High Class in Mandalamukti is $4,959 \mathrm{~km}^{2}$ (86,5\% of the area). Meanwhile, Mandalasari has 7,906 $\mathrm{km}^{2}$ (62,7\% of the area) of Very High Class. It can be concluded that the Walini area is less suitable as a candidate for the capital city of West Java and the High-Speed train station based on landslide disaster because the potential risk of Very High class is up to $50 \%$ and High class is $40 \%$ of the total area.
\end{abstract}

Keywords: landslide; risk; Walini; overlay; WLC

\section{Introduction}

Based on Indonesia Dictionary (KBBI), the capital city is the city where the central seat of government of a country, where all administrative elements, namely the executive, legislative, and judicial or the city that is the center of government. The area which is used as the capital must be a strategic area in terms of location and association with the surrounding areas. Determining an area as the capital city requires research and assessment in several ways, including disasters, society, etc. However, when an area is not suitable to be the capital city, it can be moved by considering aspects of previous research.

The relocation of the capital has been planned by the Government of West Java before. This relocation was based on the reason that the current location of the capital was no longer effective and conducive (Aida, 2019). One of the areas proposed as the new capital is the Walini area.

This landslide disaster also lurks in the Walini area as one of the areas that will be proposed to be the capital. Walini is located in Cikalongwetan District, West Bandung Regency. Physiographically, this research area belongs to the Bogor Basin Zone (Van Bemmelen, 1949, as cited in Khasanah et al., 2018). The Bogor Basin zone is a back basin of the magmatic arc that has changed from the front basin of the magmatic arc during the Early Miocene - Pliocene (Martodjojo, 1984, as cited in Khasanah et al., 2018).

The main cause that allows this landslide to occur is geographical conditions, considering that this area has a fairly high elevation. Therefore, this aspect of the feasibility of being the capital city of Walini still needs further research in terms of disasters to facilitate future development. The research carried out is about modeling the potential for landslides and knowing the feasibility level of this Walini to be the capital city in terms of its disaster aspect. This modeling is included in one of the prepared activities described in Peraturan Menteri Pekerjaan Umum dan Perumahan Rakyat Number 22/PRT/M/2018 which aims to reduce the risk caused by the disaster. 
Apart from the capital relocation project, West Java Province also has a Jakarta - Bandung High-Speed train construction project which is currently under construction. This project is a joint venture between Indonesia and China implemented under PT Kereta Cepat Indonesia-China (KCIC). Until now, the construction work has reached more than $51 \%$. Walini is also an area that is projected to be crossed by this fast train development project (Novika, 2020).

Before the construction of the Capital of West Java was carried out, it was better to conduct researches in various aspects, one of which was the landslide disaster aspect. Landslide disasters are very often found in Indonesia so it is very important to be researched. Landslide disaster research in the Walini area has never been done so this research was made. The purpose of this research is to to reveal the feasibility of the Walini area can be as the new capital city of West Java Province. The aspects studied here focus on possible disasters that can be identified with data on rainfall, slope and elevation, soil type and rock lithology, population. Apart from that, the results of this data can also be used to analyze whether this area is suitable and strategically used as an area that will be projected to be passed by the Bandung-Jakarta fast train.

\section{Study Area}

Walini area is located in Cikalong Wetan District, West Bandung Regency or coordinately located at $107^{\circ} 22^{\prime}$ 48,641" E - 107 28' 29.55" E latitude and longitude 60 44' 28,849" S - 60 46' 55,732" S (Figure 1). Walini is not an administrative area, but a tea plantation area owned by PT. Perkebunan Nusantara VIII (PTPN VIII) (Figure 2a). Maulana (2019) states that there are 3 villages covering the Walini area, including Mandalamukti, Mandalasari, and Kanangasari with a total area of $27.52 \mathrm{~km}^{2}$ (Central Bureau of Statistics (BPS) Bandung Barat Regency, 2019). 

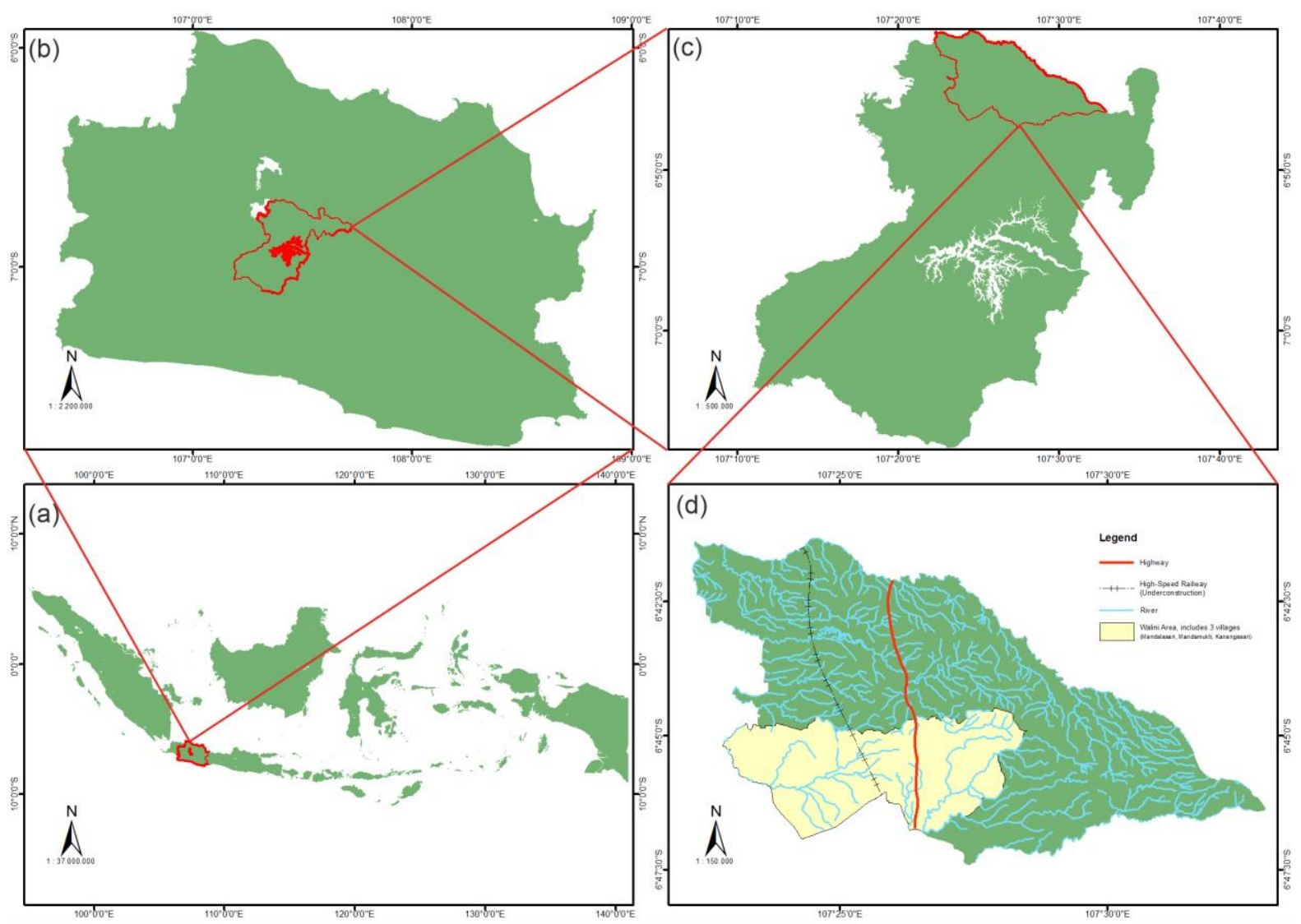

Figure 1. (a) West Java in Indonesia, (b) Bandung Barat Regency in West Java, (c) Cikalong Wetan District in Bandung Barat Regency, (d) Walini area in Cikalong Wetan District.

Andani et al. (2020) states that the Walini area is passed by one of the busiest toll roads in Java, Cipularang Toll Road (Figure 2c). It is an extension towards the outer ring road of Cikampek, Jakarta, and an alternative short road from the Jakarta Metropolitan Area (JMA) to Bandung Metropolitan Area (BMA), and vice versa (Firman, 2009). Its construction began in 2002 with a total length of $52 \mathrm{~km}$. The construction was completed in 2005 for 1.6 trillion rupiahs (Anas et al., 2015). The operation of Cipularang Toll Road makes Jakarta-Bandung travel time shorter, which initially takes 5-7 hours to become 2 hours.

Currently, one of the National Strategic Projects (PSN) which is initiated by the President of the Republic of Indonesia, Joko Widodo, is under construction in the Walini area (Figure 2b). The project is the JakartaBandung High-Speed Rail built by PT. Kereta Cepat Indonesia-China (KCIC). This High-Speed Train will cut the travel time between Jakarta and Bandung to 40 minutes. Besides, the Walini area is planned to be one of the areas of Transit-Oriented Development (TOD) Jakarta-Bandung High-Speed Rail. Based on the book The Next American Metropolis created by architect, urban designer, and urban planner Peter Calthorpe, (TOD) is a mixed-use community within an average 2,000-foot walking distance of a transit stop and core commercial area. TODs mix residential, retail, office, open space, and public use in a walkable environment, making it convenient for residents and employees to travel by transit, bicycle, foot, or car. (Calthorpe, 1993). 

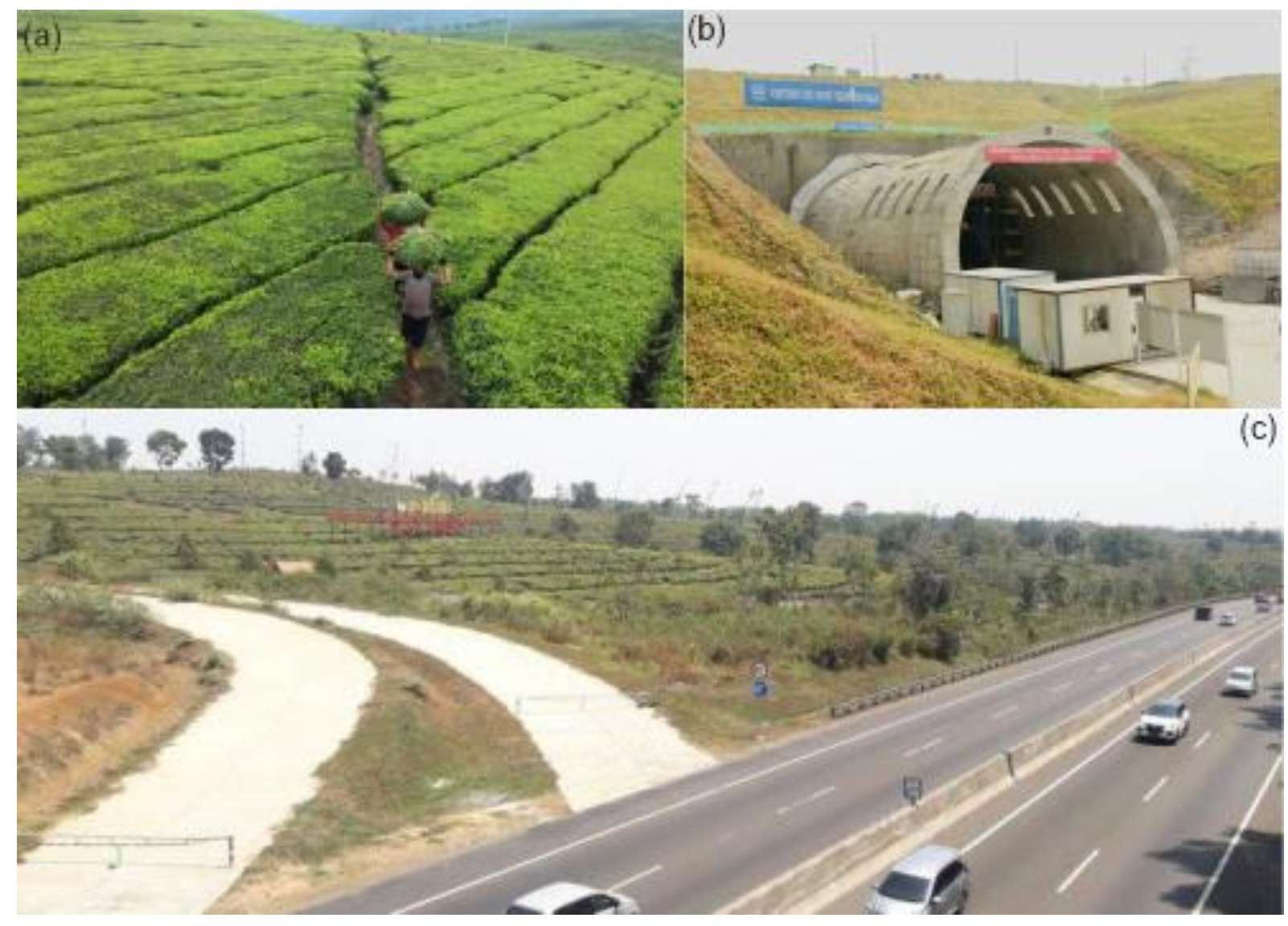

Figure 2. (a) Walini Tea Plantation (Junari, 2019), (b) Walini Tunnel of Jakarta-Bandung High-Speed Rail (Pemerintah Provinsi Jawa Barat, 2019), (c) Cipularang Toll Road (Kamaludin, 2019).

\section{Method}

In this research, The Weighted Linear Combination method (WLC) was used in this research. WLC method is one of the simplest and most common methods of multi-criteria decision-making (Baskurt \& Aydin, 2017). It is based on the decision maker's assignment of weights within each criterion. For each option, a total score is derived by multiplying the assigned weight value with a scaled value by the corresponding criterion (Hwang and Yoon, 2012, as cited in Baskurt \& Aydin, 2017). If there are m number of alternatives and $n$ number of criteria, each alternative is scored separately for each criterion. Then each criterion is given weights that indicate its importance according to other criteria. Afterward, the weighted average score for all alternatives is calculated per the following equation (Kim \& De Weck, 2006; Stanimirovic et al., 2011; Malczewski, 2000, as cited in Baskurt \& Aydin, 2017).

$A(i)=\sum_{j=1}^{n} a(i, j) \times w(j)$

Equation 1.

$A(i)$ : Weighted total score of alternative (i).

a(i,j): Score of alternative (i) according to (j) criteria.

$w(j)$ : Weight of $j$ criteria.

In terms of conditional probability, landslide risk when defined as the annual probability of loss of life of a specific individual may be calculated as follows (Morgan et al., 1992, as cited in Dai et al., 2001): 
$R(D I)=P(H) \times P(S \mid H) \times P(T \mid S) \times V(L \mid T)$

Equation 2.

$R(D I):$ the risk (annual probability of loss of life to an individual).

$P(H)$ : the annual probability of the landslide event.

$P(S \mid H)$ : the probability of spatial impact given the event.

$P(T \mid S)$ : the probability of temporal impact given the spatial impact.

$V(L \mid T)$ : the vulnerability of the individual (probability of loss of life of the individual given impact).

For a case involving property damage, the equivalent expression would be

$R(P D)=P(H) \times P(S \mid H) \times V(P \mid S) \times E$

Equation 3.

$R(P D)$ : the risk (annual loss of property value).

$P(H)$ : the annual probability of the landslide event.

$P(S \mid H)$ : the probability of spatial impact (i.e. of the landslide impacting the property).

$V(P \mid S)$ : the vulnerability of the property (proportion of property value lost).

E: the element at risk (e.g. the value of the property).

Some researchers considered the product of $P(S \mid H) \times P(T \mid S) \times V(L \mid T)$ in Eq. 2 or $P(S \mid H) \times V(P \mid S) \times E$

in Eq. 3 as consequence (Wong et al., 1997, as cited in Dai et al., 2001) or the product of $P(H) \times P(S \mid H)$ as hazard (Leroueil \& Locat, 1998, as cited in Dai et al., 2001). 


\section{Data}

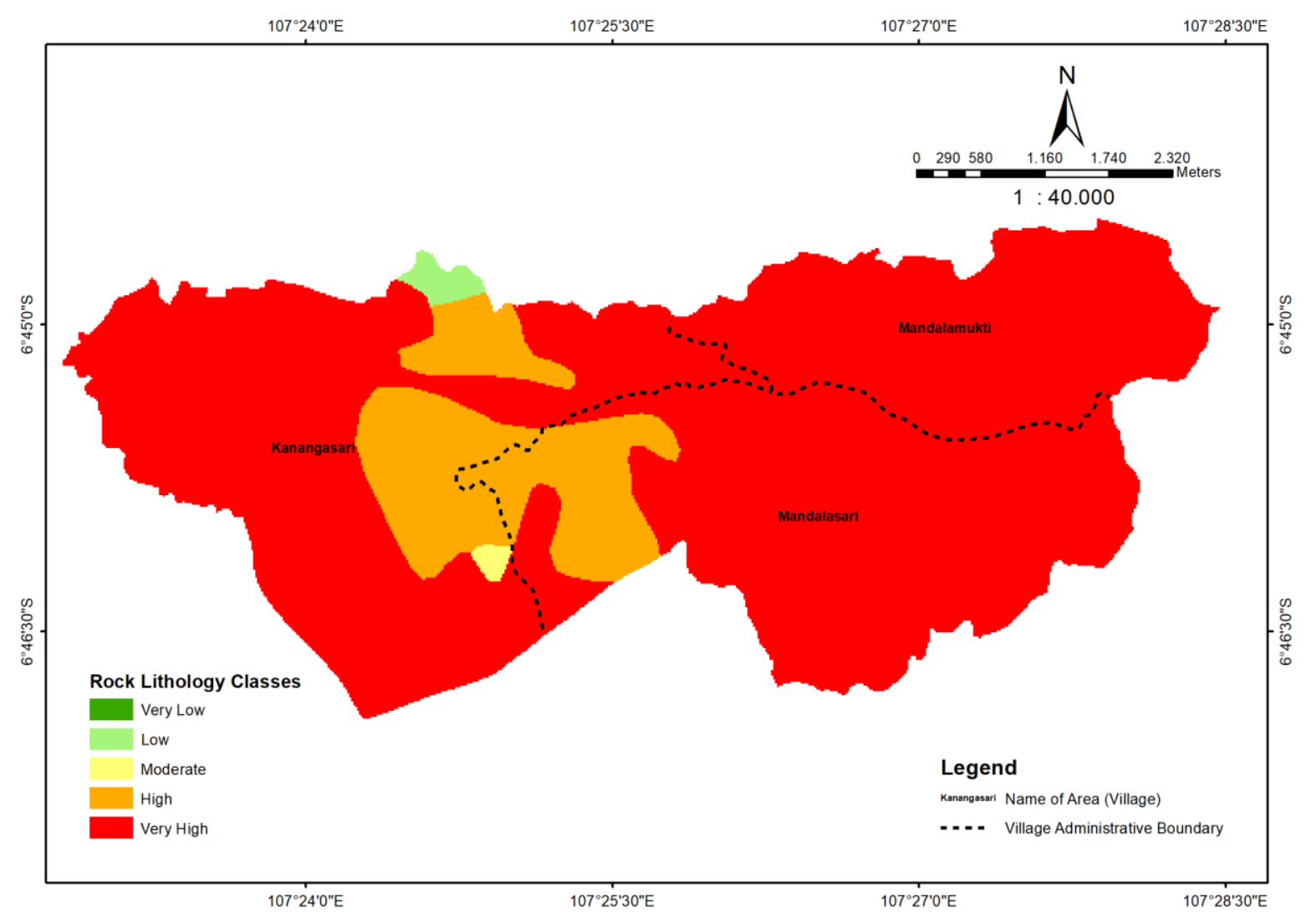

Figure 3. Rock Lithology Map

The map of rock lithology (Figure 3) in the Walini area was obtained by digitizing the Cianjur Sheet Regional Geological Map on a scale of 1:100.000 (Center of Geological Research and Development, 1994). Based on digitization results, the map consists of 4 rock lithologies, including Cantayan Formation, Claystone Member (Mttc), Cantayan Formation, Sandstone Member (Mtts), Older Volcanic Products (Qob), and Jatiluhur Formation, Marl and Quartz Sandstone Member (Mdm). Mttc and Mtts are in the Cantayan Formation, but Mttc is filled by claystone, tuffaceous shale containing sulfur, lignite, and claystone concretions, while Mtts is filled by well-bedded dirty sandstone, sandy shale, shaly clay, marine breccia, and conglomerate. Qob is an older volcanic product where there is a volcanic breccia, flow breccia, lava deposits, and lava showing sheet and columnar jointing. Broadly enough, the Wanili area is dominated by the Frozen Rocks of the Qob unit. Mdm is dark gray marl, marl claystone, and clay shale with intercalations of quartz sandstone quartzite, and marl limestone. The soil in the Walini area has 2 types that spread over this research area, namely latosol and andosol. 

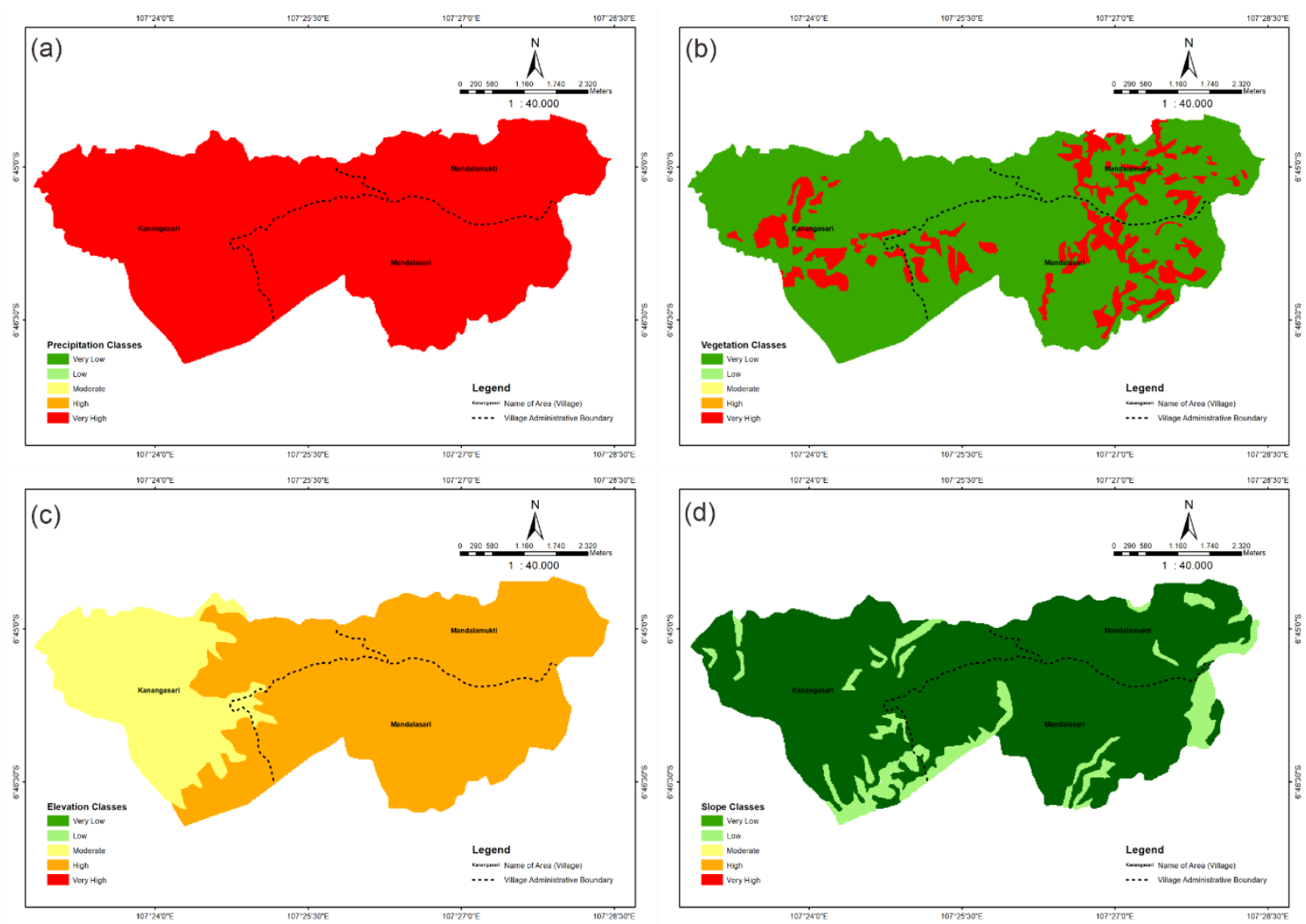

Figure 4. (a) Rainfall Map, (b) Vegetation Map, (c) Elevation Map, (d) Slope Map

Rainfall data is obtained from the Japan Meteorological Agency (JMA) with period of 5 years (2015 - 2019). The map shows that the rainfall in the Walini area above $2000 \mathrm{~mm} /$ year (Figure 4a.). Vegetation data is obtained from Badan Informasi Geospasial (BIG) then using the overlay method. Walini area is dominated by vegetation (Figure 4b.). The DEM and the vector data of the administrative district of the Walini area provided elevation information and were used to extract the slope information of parts of the Walini area. The elevation of the Walini area is around 300 to 800 masl (meters above sea level) that spreads over this area which is shown in Figure $4 \mathrm{c}$. that from East to West has a high fluctuation which is quite significant, the Western part is the lowest while the Eastern part is the highest. Slope data shows that this area is dominated by numbers $<15^{\circ}$, and there are several zones with a slope of $15^{\circ}-25^{\circ}$. (Figure $4 \mathrm{~d}$ ). 

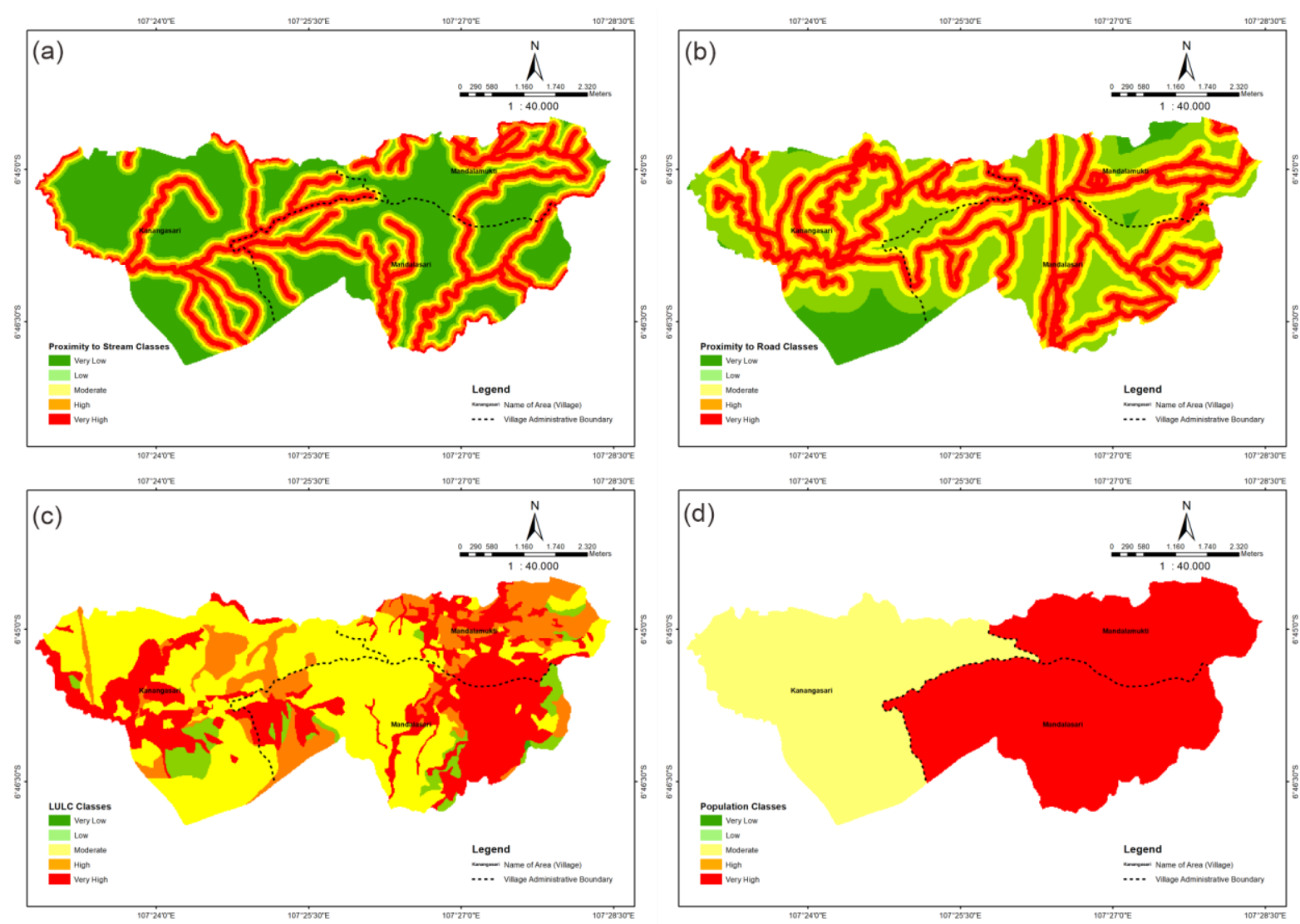

Figure 5. (a) Proximity to Stream Map, (b) Proximity to Road Map, (c) LULC Map, (d) Population Map

Proximity to road and proximity to stream use BIG's vector data, then the data is processed using buffer method on software. Hydrology analysis enables surface water stream in the road corridor to be mapped. This is initiated by modeling hydrological fill from vector data. Then, flow direction and flow accumulation in the area where surface water streams affect the road were modeled. It can be seen in Figure 5a and 5b. LULC data is obtained from BIG then using the overlay method. The map shows that the Walini area is dominated by plantations, rice fields, and settlement. Population data is obtained from Badan Pusat Statistik Kabupaten Bandung Barat (2019). The data shows that the population of Mandalasari and Mandalamukti is above 10000 people and Kanangasari's population is between $5000-10000$ people (Figure 5d.)

\section{Results and Discussions}

\section{Landslide Hazard Assessment}

The landslide hazard assessment map was based on landslide causative parameters and the weights were provided as Equation below.

\section{$L S=$ Rainfall $\times 0.3+$ Geology $\times 0.3+$ Elevation $\times 0.2+$ Slope $\times 0.1+$ Vegetation $\times 0.1$}

where LS is landslide susceptibility. The weights are assigned using GIS overlay capability, based on its influence on a landslide in comparison to other parameters and performing a weighted sum to combine the parameters. For landslide hazard assessments, there are 5 parameters with their categories and has been weighted based on the data in this research area. The following is a table of data parameters (Table 1)

Table 1. Parameters of Landslide Hazard Assessment 


\begin{tabular}{|c|c|c|c|c|}
\hline \multicolumn{2}{|c|}{ Parameters } & \multirow{2}{*}{$\begin{array}{c}\text { Classes } \\
\text { Very Low }\end{array}$} & \multirow{2}{*}{$\begin{array}{c}\text { Values } \\
1\end{array}$} & \multirow[t]{2}{*}{ Weight $(\%)$} \\
\hline \multirow{5}{*}{ Rainfall (mm/year) } & $<500$ & & & \\
\hline & $501-1000$ & Low & 2 & \multirow{4}{*}{30} \\
\hline & $1001-1500$ & Medium & 3 & \\
\hline & $1501-2000$ & High & 4 & \\
\hline & $>2000$ & Very High & 5 & \\
\hline \multirow{4}{*}{ Geology } & $\begin{array}{l}\text { Mdm, Latosol \& } \\
\text { Andosol }\end{array}$ & Low & 2 & \multirow{4}{*}{30} \\
\hline & $\begin{array}{l}\text { Mttc, Latosol \& } \\
\text { Andosol }\end{array}$ & Medium & 3 & \\
\hline & $\begin{array}{l}\text { Mtts, Latosol \& } \\
\text { Andosol }\end{array}$ & High & 4 & \\
\hline & $\begin{array}{l}\text { Qob, Latosol \& } \\
\text { Andosol }\end{array}$ & Very High & 5 & \\
\hline \multirow{2}{*}{ Vegetation } & Vegetated & Very Low & 1 & \multirow{2}{*}{10} \\
\hline & Non-Vegetated & Very High & 5 & \\
\hline \multirow{5}{*}{ Slope $\left(^{\circ}\right)$} & $<15$ & Very Low & 1 & \multirow{5}{*}{10} \\
\hline & $15-25$ & Low & 2 & \\
\hline & $25-35$ & Medium & 3 & \\
\hline & $35-45$ & High & 4 & \\
\hline & $>45$ & Very High & 5 & \\
\hline \multirow{5}{*}{ Elevation (masl) } & $<0$ & Very Low & 1 & \multirow{5}{*}{20} \\
\hline & $0-200$ & Low & 2 & \\
\hline & $200-500$ & Medium & 3 & \\
\hline & $500-1000$ & High & 4 & \\
\hline & $>1000$ & Very High & 5 & \\
\hline
\end{tabular}

Rainfall data is classified into five classes $(<500,501-1000,1001-1500,1501-2000,>2000)$ based on Gaussen \& Chatefort (1978) as cited in Putra (2018). In the geological parameters, we divide by formation using porosity, sorting, mineral content, and density of joints considerations. Vegetation parameters are classified based on the presence of vegetation (Dikshit et al., 2020). Slope and Elevation is classified into 5 classes from $<15$ to $>45$ for slope (Bijukchhen et al., 2012); and <0 to >1000 for elevation (Chen et al., 2014). After that, we use the WLC method using these 5 parameters to make a Landslide Hazard Assessment Map (Figure 6.). Hazard map is divided into five classes: Very Low (0-0.33), Low (0.34-0.44), Moderate (0.45-0.58), High (0.59-0.72), and Very High (0.73-1) (Dikshit et al., 2020). 


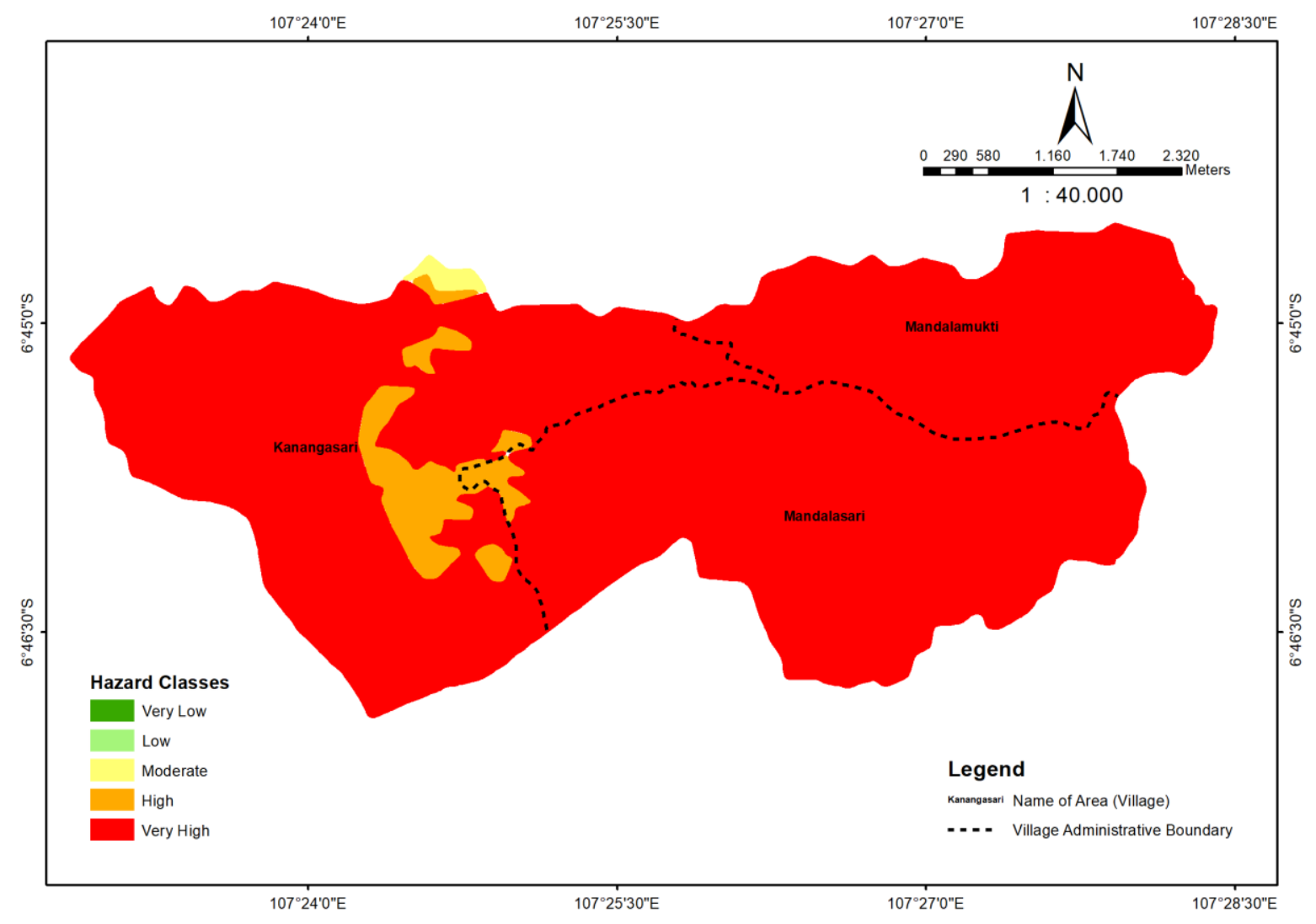

Figure 6. Landslide Hazard Assessment Map.

The maps derived using both the components resulted in the hazard map. Figure 6 represents the landslide hazard map, which has been divided into five classes: Very Low, Low, Moderate, High, and Very High. The results show that the Very High potential dominates this area with $26,66472 \mathrm{~km}^{2}$ or around $95,4 \%$ of the total area. Moderate and High potential covers a small part of the village of Kenangasari. For more information can be seen in Table 2.

Table 2. Area Distribution of Hazard Class

\begin{tabular}{ccc}
\hline Hazard Class & Area $\left(\mathrm{Km}^{2}\right)$ & Area $(\%)$ \\
\hline Moderate & 0,122491 & 0,4 \\
\hline High & 1,238969 & 4,4 \\
\hline Very High & 26,66472 & 95,4 \\
\hline
\end{tabular}

\section{Landslide Vulnerability Assessment}

The vulnerability assessment is defined as the expected degree of loss for elements at risk due to a certain event, with values ranging between 1 (very low) to 5 (very high) based on parameters at risk, like population density, land use/land cover (LULC), proximity to the road, and proximity to streams.

\section{$L V=$ Population $\times 0.3+L U L C \times 0.2+$ Proximi ty to road $\times 0.3+$ Proximi ty to stream $\times 0.2$}

where LV is a landslide vulnerability. The vulnerability was developed and classified into five classes based on the natural breaks classification technique.

Table 3.Parameters of Landslides Vulnerability Assessment 


\begin{tabular}{|c|c|c|c|c|}
\hline \multicolumn{2}{|c|}{ Parameters } & Classes & Values & Weight (\%) \\
\hline \multirow{3}{*}{ Population } & $<5000$ & Very Low & 1 & \multirow{3}{*}{30} \\
\hline & $5000-10000$ & Moderate & 3 & \\
\hline & $>10000$ & Very High & 5 & \\
\hline \multirow{5}{*}{ LULC } & \multirow{5}{*}{$\begin{array}{c}\text { Natural Forest } \\
\text { Shrub, Field } \\
\text { Plantation } \\
\text { High Yard } \\
\text { Rice Field \& } \\
\text { Settlement }\end{array}$} & Very Low & 1 & \multirow{5}{*}{20} \\
\hline & & Low & 2 & \\
\hline & & Moderate & 3 & \\
\hline & & High & 4 & \\
\hline & & Very High & 5 & \\
\hline \multirow{5}{*}{ Proximity to Road (m) } & $>500$ & Very Low & 1 & \multirow{5}{*}{30} \\
\hline & $200-500$ & Low & 2 & \\
\hline & $100-200$ & Moderate & 3 & \\
\hline & $50-100$ & High & 4 & \\
\hline & $0-50$ & Very High & 5 & \\
\hline \multirow{5}{*}{ Proximity to Stream (m) } & $>200$ & Very Low & 1 & \multirow{5}{*}{20} \\
\hline & $150-200$ & Low & 2 & \\
\hline & $100-150$ & Moderate & 3 & \\
\hline & $50-100$ & High & 4 & \\
\hline & $0-50$ & Very High & 5 & \\
\hline
\end{tabular}

It can be seen in Figure 4c in Table 3, Population is divided into 3 classes: $<5000,5000-10000$, and $>10000$. LULC classes are based on Glade (2003) classification, then it is divided into 5 classes. Proximity to Stream and Proximity to Road are classified into five classes: $0-50,50-100,100-150,150-200$ and $>200$ meter for stream (Mersha \& Meten, 2020); and 0-50, 50-100,100-200, 200-500, >500 for road (Arsyad \& Hamid, 2019). After that, we use the WLC method using these 4 parameters to make a Landslide Vulnerability Assessment Map (Figure 7.). Vulnerability map is divided into five classes: Very Low $(0-0.36)$, Low (0.37-0.48), Moderate (0.49-0.64), High (0.65-0.76), and Very High (0.77-1) (Dikshit et al., 2020). 


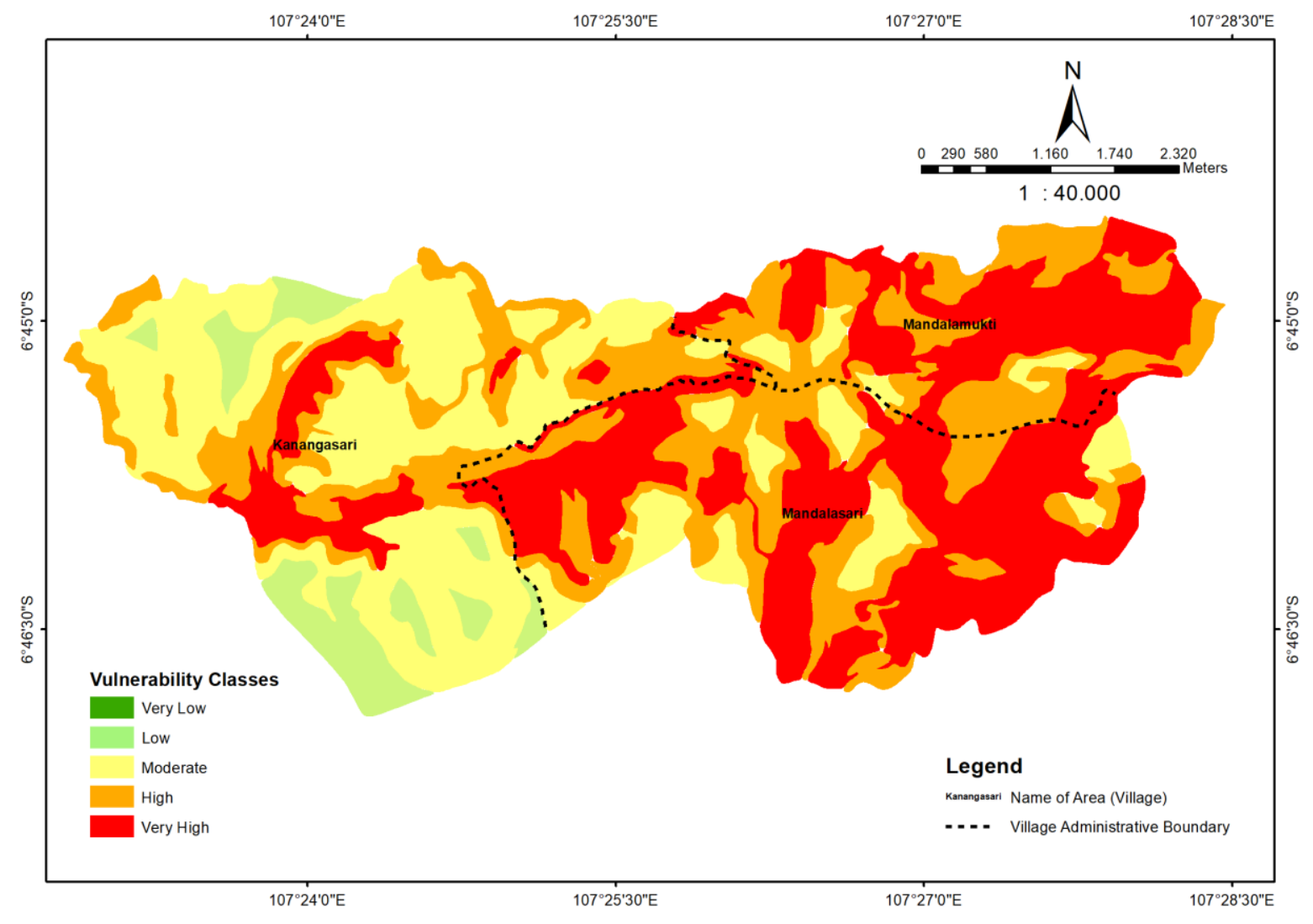

Figure 7. Landslide Vulnerability Assessment Map.

The maps derived using both the components resulted in the Vulnerability map. Figure 7 represents the landslide vulnerability map, which has only 4 classes. Mandalasari and Mandalamukti have Very High Class potential dominance with $10,25789 \mathrm{~km}^{2}$ or around $34,5 \%$ of the area. The following is a table of area distribution of vulnerability class (Table 4).

Table 4. Area Distribution of Vulnerability Class

\begin{tabular}{ccc}
\hline Vulnerability Class & Area $\left(\mathrm{Km}^{2}\right)$ & Area $(\%)$ \\
\hline Low & 1,608293 & 5,5 \\
\hline Moderate & 8,405723 & 29 \\
\hline High & 8,726060 & 30 \\
\hline Very High & 10,25789 & 34,5 \\
\hline
\end{tabular}

\section{Landslide Risk Assessment}

The risk map was developed by multiplying the landslide hazard and vulnerability map. Such a study would also help in estimating the vulnerable area and the impact of any landslide event in the foreseeable future. We can obtain the Risk Map using the equation below:

\section{Risk $=$ Haz ard $\times$ Vulnerability}

The obtained map was classified into three classes: Moderate, High, and Very High based on the WLC method of Landslide Hazard and Vulnerability Map. The obtained map was classified into five classes: Very Low (0- 
0.12), Low (0.13-0.21), Moderate (0.22-0.37), High (0.38-0.55), and Very High (0.56-1) based on the natural break classification technique (Park et al., 2018 as cited in Dikshit et al., 2020). It can be seen in Figure 8.

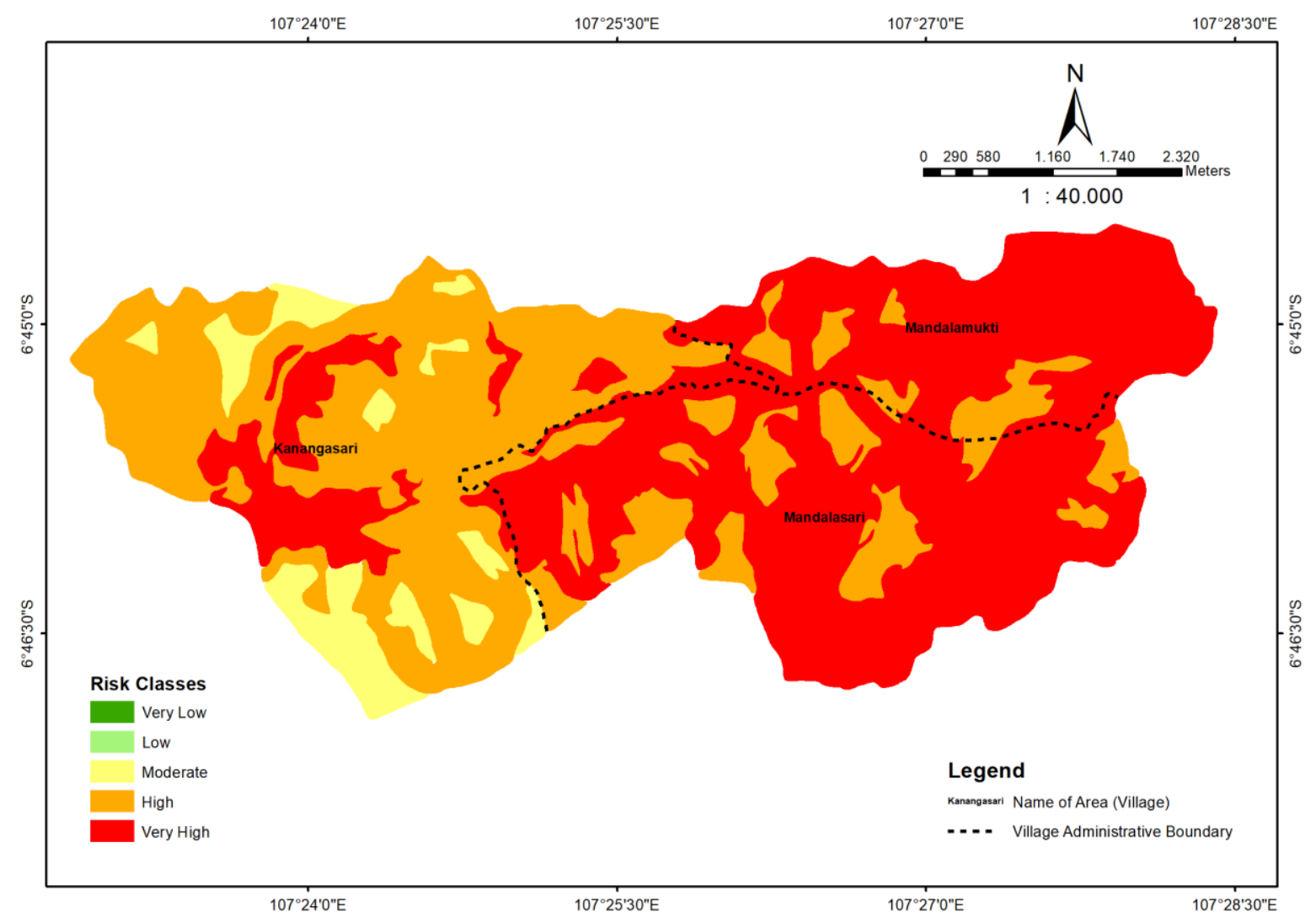

Figure 8. Landslide Risk Assessment Map.

Kenangasari is covered by 3 classes and dominated by High Class Risk; Mandalasari is covered by 2 classes and dominated by Very High Class Risk; Mandalamukti is covered by 2 classes and dominated by Very High Class Risk. The following is a table of area distribution of risk class (Table 5).

Table 5. Area Distribution of Risk Class

\begin{tabular}{ccc}
\hline Risk Class & Area $\left(\mathrm{Km}^{2}\right)$ & Area (\%) \\
\hline Moderate & 1,7646447 & 6 \\
\hline High & 11,307004 & 40 \\
\hline Very High & 14,947296 & 54 \\
\hline
\end{tabular}

\section{Conclusion}

Walini area is one of the areas that will be proposed to be the capital. It is located in Cikalongwetan District, West Bandung Regency has the potential for landslides to occur due to many factors. The purpose of this study is to reveal the potential landslides in this area to get a conclusion of whether this area is feasible or not. We used WLC as our method by using Landslide Hazard Assessment parameters (rainfall, geology, slope, elevation, vegetation) and Landslide Vulnerability Assessment parameters (population, LULC, proximity to the road, proximity to stream). After we obtained a hazard assessment map and vulnerability assessment map, then we overlay to get the Landslide Risk Assessment Map. Based on the landslide potential risk result, we can conclude that the Walini area is not suitable as a candidate for the capital city of West Java and the fast train station because the potential risk of Very High class is up to $50 \%$ and High class is $40 \%$ of the total area, with Mandalamukti and Mandasari Villages has dominated by Very High class. 
This research is carried out only from the geological aspect so that it requires in-depth research to determine the danger of landslides. The limit exists due to various factors, one of which is the Covid-19 so that the necessary data is limited. We are encouraged to conduct further research in the social and economic aspects because landslide disasters are not only about nature but there are communities in them.

\section{Acknowledge}

The authors are thankful to the Faculty of Geological Engineering Padjadjaran University, Badan Geologi for Geological data, Japan Meteorological Agency for providing rainfall data, Badan Informasi Geospasial for providing DEM and vector data, and Badan Pusat Statistik Kabupaten Bandung Barat for providing population data.

\section{References}

Aida, N. (2019). Wacana Ibu Kota Jabar Pindah, Ini Alasan Hingga Calon Lokasinya. Retrieved from https://www.kompas.com/tren/read/2019/08/30/060000365/wacana-ibu-kota-jabar-pindah-ini-alasan-hingga-calonlokasinya?page $=$ all

Anas, R., Tamin, O. Z., \& Wibowo, S. S. (2015). Applying input-output model to estimate the broader economic benefits of Cipularang Tollroad Investment to Bandung District. In Procedia Engineering. Retrieved from https://doi.org/10.1016/j.proeng.2015.11.042

Andani, I. G. A., La Paix Puello, L., \& Geurs, K. (2020). Exploring the role of toll road construction on residential location choice in the Jakarta - Bandung region. Case Studies on Transport Policy. Retrieved from https://doi.org/10.1016/j.cstp.2020.02.001

Arsyad, A., \& Hamid, W. (2020). Landslide susceptibility mapping along road corridors in west Sulawesi using GIS-AHP models. In IOP Conference Series: Earth and Environmental Science. Retrieved from https://doi.org/10.1088/1755$\underline{1315 / 419 / 1 / 012080}$

Baskurt, Z. M., \& Aydin, C. C. (2018). Nuclear power plant site selection by Weighted Linear Combination in GIS environment, Edirne, Turkey. Progress in Nuclear Energy. Retrieved from https://doi.org/10.1016/j.pnucene.2017.09.004

Bijukchhen, S. M., Kayastha, P., \& Dhital, M. R. (2013). A comparative evaluation of heuristic and bivariate statistical modelling for landslide susceptibility mappings in Ghurmi-Dhad Khola, east Nepal. Arabian Journal of Geosciences. Retrieved from https://doi.org/10.1007/s12517-012-0569-7

Calthorpe, P. (1993). The Next American Metropolis: Ecology, Community, and the American Dream. Princeton $\begin{array}{llll}\text { Architectural } & \text { Press. } & \text { Retrieved }\end{array}$ https://books.google.co.id/books?id=WtKU5L0ajA8C\&lpg=PA9\&ots=FAnhZzrifL\&lr\&hl=id\&pg=PA9\#v=onepage\&q\&f=f $\underline{\text { alse }}$

Chen, X., Hu, T., Ren, F., Chen, D., Li, L., \& Gao, N. (2014). Landscape analysis of geographical names in Hubei Province, China. Entropy. Retrieved from https://doi.org/10.3390/e16126313

Dai, F. C., Lee, C. F., \& Ngai, Y. Y. (2002). Landslide risk assessment and management: An overview. Engineering Geology. Retrieved from https://doi.org/10.1016/S0013-7952(01)00093-X

Dikshit, A., Sarkar, R., Pradhan, B., Acharya, S., \& Alamri, A. M. (2020). Spatial landslide risk assessment at Phuentsholing, Bhutan. Geosciences (Switzerland). Retrieved from https://doi.org/10.3390/geosciences 10040131

Firman, T. (2009). The continuity and change in mega-urbanization in Indonesia: A survey of Jakarta-Bandung Region (JBR) development. Habitat International. Retrieved from https://doi.org/10.1016/j.habitatint.2008.08.005

Glade, T. (2003). Landslide occurrence as a response to land use change: A review of evidence from New Zealand. In Catena. Retrieved from https://doi.org/10.1016/S0341-8162(02)00170-4

Hwang, Ching-Lai; Yoon, K. (1981). Multiple Attribute Decision Making: Methods and Applications A State-of-the -Art Survey. Springer-Verlag Berlin Heidelberg New York (Vol. 186, p. 228). Springer Berlin Heidelberg. Retrieved from https://doi.org/10.1007/978-3-642-48318-9

Ibu Kota (def.1). (n.d). Kamus Besar Bahasa Indonesia $\quad$ (KBBI). Retrived from https://kbbi.kemdikbud.go.id/entri/ibu\%20kota

Junari, T. (2019). Walini Tea Plantation. https://ayobandung.com/read/2019/08/29/62021/walini-lebih-unggul-jadi-ibu-kotaprovinsi-jabar

Kamaludin, H. (2019). Cipularang Toll Road. https://jabar.tribunnews.com/2019/08/30/laporan-langsung-dari-walinikondisi-terkini-lokasi-disebut-ridwan-kamil-akan-jadi-ibu-kota-baru 
Kementerian Pekerjaan Umum dan Perumahan Rakyat. (2018). Peraturan Menteri Pekerjaan Umum dan Perumahan Rakyat Nomor 22/PRT/M/2018 Tahun 2018. Retrived from https://jdih.pu.go.id/detail-dokumen/2594/1

Khasanah, W., Najib, N., \& Buana, T. W. (2018). Re-Evaluasi Perencanaan Pengembangan Kota Baru Berdasarkan Informasi Geologi Teknik di Walini, Kecamatan Cikalong Wetan, Kabupaten Bandung Barat, Provinsi Jawa Barat. Jurnal Geosains Dan Teknologi. Retrieved from https://doi.org/10.14710/jgt.1.3.2018.113-123

Kim, I. Y., \& De Weck, O. L. (2006). Adaptive weighted sum method for multiobjective optimization: A new method for Pareto front generation. Structural and Multidisciplinary Optimization. Retrieved from https://doi.org/10.1007/s00158-005$\underline{0557-6}$

Leroueil, S., \& Locat, J. (1998). Slope movements - geotechnical characterization, risk assessment and mitigation. In: Maric, B., Lisac, L., Szavits-Nossan, A. (Eds.), Geotechnical Hazards. Balkema, Rotterdam, Pp. 95-106.

Malczewski, J. (2000). On the use of weighted linear combination method in GIS: Common and best practice approaches. Transactions in GIS. https://doi.org/10.1111/1467-9671.00035

Martodjojo, S. (2003). Evolusi Cekungan Bogor Jawa Barat. Penerbit ITB, Bandung.

Maulana, Y. (2019). Penampakan Walini yang Diproyeksikan Jadi Ibu Kota Jabar. Retrieved from https://news.detik.com/berita-jawa-barat/d-4687198/penampakan-walini-yang-diproyeksikan-jadi-ibu-kota-jabar

Mersha, T., \& Meten, M. (2020). GIS-based landslide susceptibility mapping and assessment using bivariate statistical methods in Simada area, northwestern Ethiopia. Geoenvironmental Disasters. Retrieved from https://doi.org/10.1186/s40677-020-00155-X

Morgan, G.C., Rawlings, G.E., \& Sobkowicz, J.C. (1992). Evaluating total risk to communities from large debris flows. Proceedings of 1st Canadian Symposium on Geotechnique and Natural Hazards. Bitech Publishers, Vancouver, Bc, Canada, pp. 225-236.

Novika, S. (2020). Apa Kabar Proyek Kereta Cepat Jakarta-Bandung?. Retrieved from https://finance.detik.com/beritaekonomi-bisnis/d-5145690/apa-kabar-proyek-kereta-cepat-jakarta-bandung

Pardeshi, S. D., Autade, S. E., \& Pardeshi, S. S. (2013). Landslide hazard assessment: Recent trends and techniques. SpringerPlus. Retrieved from https://doi.org/10.1186/2193-1801-2-523

Park, S. J., Lee, C. W., Lee, S., \& Lee, M. J. (2018). Landslide susceptibility mapping and comparison using decision tree models: A case study of Jumunjin Area, Korea. Remote Sensing. Retrieved from https://doi.org/10.3390/rs10101545

Pellicani, R., Argentiero, I., \& Spilotro, G. (2017). GIS-based predictive models for regional-scale landslide susceptibility assessment and risk mapping along road corridors. Geomatics, Natural Hazards and Risk. Retrieved from https://doi.org/10.1080/19475705.2017.1292411

Pemerintah Provinsi Jawa Barat. (2019). Walini Tunnel of Jakarta-Bandung High-Speed Rail. Retrieved from https://www.jabarprov.go.id/index.php/news/33057/2019/05/14/Tunnel-Walini-Berhasil-Ditembus-Gubernur-Luar-Biasa

Putra, A., Ratnaningsih, A. T., \& Ikhwan, M. (2018). Pemetaan daerah rawan kebakaran hutan dan lahan dengan menggunakan sistem informasi geografis (studi kasus: kecamatan bukit batu, kab. Bengkalis). Wahana Forestra: Jurnal Kehutanan. Retrieved from https://doi.org/10.31849/forestra.v13i1.1555

Singh, A., Pal, S., \& Kanungo, D. P. (2020). An integrated approach for landslide susceptibility-vulnerability-risk assessment of building infrastructures in hilly regions of India. Environment, Development and Sustainability. Retrieved from https://doi.org/10.1007/s10668-020-00804-z

Stanimirović, I. P. S., Zlatanović, M. L., \& Petković, M. D. (2011). on the Linear Weighted Sum Method for MultiObjective Optimization *. Facta Universitatis (NIŠ) Ser. Math. Inform, 26, 49-63. Retrieved from http://facta.junis.ni.ac.rs/mai/mai26/fumi-26_49_63.pdf

Sujatmiko. (1994). Peta Geologi Lembar Cianjur skala 1:100.000. Puslitbang Geologi, Bandung.

Tavipian, Y., E. (2019). Cikalongwetan In Numbers. Badan Pusat Statistik Kabupaten Bandung Barat. 22.

Van Bemmelen, R. W. (1949). The Geology of Indonesia. General Geology of Indonesia and Adjacent Archipelagoes. Government Printing Office, The Hague.

Wong, H. N., Ho, K. K. S., \& Chan, Y. C. (2018). Assessment of consequence of landslides. In Landslide Risk Assessment (pp. 111-149). Routledge. Retrieved from https://doi.org/10.1201/9780203749524-5 